\title{
Amimetic assets and persistent profits under competition
}

\section{Robert Gmeiner $^{1}$}

Published online: 31 July 2019

(C) The Sunwater Institute 2019

\begin{abstract}
Some industries are very dynamically competitive and characterized by much entrepreneurial innovation. Others are oligopolistic and still others are known for state favors and regulatory rents. In a market economy, competitive pressures cause businesses to continually adapt to changing conditions. Different approaches can be taken entrepreneurial innovation, consolidation, and rent seeking are examples. This paper examines the characteristics of firms and productive assets that preserve an innovative, dynamic economy and hedge against rent seeking and crony capitalism. In an innovative, dynamic economy, profits can only be sustained against competition if a business has productive assets that offer a unique advantage over competitors. These assets can be termed amimetic assets, a term based on the Greek word amimitos, meaning "inimitable." When these assets can be acquired or developed through entrepreneurial discovery, business models can be oriented to exploit them. If this is more difficult in an industry, it will be more likely to be characterized by regulation and regulatory rents. Amimetic assets are thus fundamental to an innovative economy and are a major factor among many in determining whether a business obtains profits through repeated entrepreneurial discovery or rent seeking.
\end{abstract}

Keywords Innovation · Rent seeking · Property rights · Entrepreneurship · Dynamic competition

JEL codes $\mathrm{D} 21 \cdot \mathrm{D} 23 \cdot \mathrm{M} 21 \cdot \mathrm{O} 31 \cdot \mathrm{P} 14$

\section{Introduction}

Industries in developed economies are characterized by varying degrees of price competition, innovation and entrepreneurship, and government intervention. Some

Robert Gmeiner

rgmeiner@ sunwater.org

1 Scholar, Sunwater Institute, 12358 Parklawn Dr, North Bethesda, MD 20852, USA 
sectors are dynamic and innovative, and others are characterized by stiff price competition. Oligopoly and monopoly characterize still others. Some industries are known for successfully seeking regulatory rents. This paper addresses the question of why firms in some industries behave competitively in the market but firms in other industries tend toward rent seeking. Although there are many types of economic rents, such as monopoly rents, scarcity rents, or Ricardian rents, for the sake of parsimony, this paper uses the term "rent seeking" to refer to the seeking of regulatory rents and other state favors.

Competition to innovate and realize profit from unexploited sources is more important than competition to reduce prices. Profit comes from exploiting opportunities that have not yet been commercialized, which are found through the process of entrepreneurial discovery. This frequently involves producing new, unique advantages that had not been seen before and, as a result, were underpriced by the market. When done successfully, profits are the reward for the entrepreneur, which last until competition erodes them as prices adjust. Without the profits that come from entrepreneurial discovery, the tendency is toward price competition. This can result in consolidation and rent seeking behavior. This paper addresses the question of why some industries are innovatively competitive and others are dominated by rent seeking. In so doing, it develops a new theory based on characteristics of an industry's productive assets that yield persistent profits over the long term which the market does not compete away, even as entrepreneurial discovery by competitors continues. Absent these characteristics, which this paper describes, incentives for rent seeking are magnified.

All firms in a given industry use similar or identical assets for production of similar goods or services. The prospect of increased profits is an incentive for entrepreneurial innovation. Profits can be had if the productive asset, or property that a business exploits, offers a unique advantage that a competitor cannot trivially duplicate or impede. I term these business assets amimetic assets, from the Greek word amimitos ("inimitable"). Without such assets, firms look for other means to protect their profits. Rent seeking becomes attractive in these situations.

Section 1 describes existing literature on market structure and innovation and is followed in section 2 by a description of the idea of property as a foundation for innovation and creative destruction. Section 3 details with examples the idea of amimetic assets, complementary to which section 4 overviews the role of amimetic assets in maintaining an innovative, dynamic economy. Section 5 provides empirical support.

\section{Innovation and the market process}

Some industries are competitive with much entrepreneurial innovation. Software and pharmaceuticals are examples. Others are dominated by large firms, but exhibit little innovation, such as petroleum refining, although petroleum extraction is quite innovative. Still other industries exhibit near-perfect price competition, but are characterized by little innovation, such as field crop agriculture. ${ }^{1}$ Many industries

\footnotetext{
${ }^{1}$ In the United States, field crop agriculture exhibits near-perfect price competition, but is distorted by federal agricultural subsidies.
} 
for which innovation and entrepreneurial discovery in general seem uncommon do have more innovative support industries. For field crop agriculture, these are the very innovative industries of seed production and agricultural machinery, which are dominated by large companies.

Kamien and Schwartz (1982) survey literature and delve into the issue of how market structure affects innovation, broadly concluding that innovation is most prevalent in a structure between the extremes of perfect price competition and monopoly. Regardless of structure, a market is competitive if entrepreneurial discovery can take place (Kirzner [1973] 2013). Because innovation is a result of entrepreneurial discovery of arbitrage opportunities over time in procuring or creating productive assets, it is not surprising that it tends to thrive in an environment between these two extremes. Perfect price competition leaves little room for entrepreneurial competition and monopolies are often state-supported in practice.

Innovation is a result of entrepreneurial alertness and subjective valuation of assets which lead the entrepreneur to act on a potential profit opportunity. The first entrepreneur who correctly perceives that an asset can be obtained or created for less than it will return when implemented will be rewarded with profit. The asset was thus underpriced. If it was not an amimetic asset, market forces will cause its price to adjust and profits will not persist. If it was an amimetic asset, the entrepreneur will continue to reap profits over the long term because its advantage is not replicable and is thus not traded in the market. The entrepreneurial profit from successfully procuring or creating an amimetic asset is a result both of exceptionally good alertness and perception of the asset's value.

Whether or not the entrepreneurial process of discovery tends to yield amimetic assets in an industry can in turn affect the market structure of that industry. Further incentives for discovery or rent seeking in turn shape actions that affect the competitive nature and entrepreneurial environment of the industry. In contrast to the existing literature on the effect of innovation on market structure, this paper examines distinct issue of the effect of innovation on market structure and competition seen through the lens of entrepreneurial discovery and amimetic assets.

In The Innovator's Dilemma (1997), Christensen writes that as innovative companies become large, they are threatened by other innovators. Their profits are a signal to would-be entrepreneurs that productive effort may be well-rewarded in that industry. At first, the soon-to-be challengers are not targeting the large incumbent's own customer base; they are also too small for the incumbent to see value in directly competing with them. As the challengers grow, it can quickly become too late for the incumbent to react. Innovation is a constant threat that can displace successful, established firms. Market power is no advantage, and market structure is meaningless, if entry is possible and entrepreneurial discovery can realistically take place.

\section{Assets, property, and property rights}

This section lays a foundation for the idea of assets, and property more broadly, not just property rights, as a foundation for an innovative, dynamically competitive economy and a hedge against incentives for rent seeking. Property rights define acceptable conduct between persons relating to other objects, which are property. Modern 
capitalism developed largely because well-defined property rights gave rise to incentives for economic activity, which was possible because the property itself offered profit potential. Assets, a form of property used for productive activity, are what entrepreneurs must perceive to be priced lower than their expected return before engaging in market activity. This only occurs when a legal regime of transparent, recognized, and welldefined property rights makes possible the exchange of property. (Hodgson 2015). Property rights are a sine qua non of a functioning economy.

Although property is a complex matter in modern economies, this paper relies on four basic rights. These four rights include the rights to 1) use, 2) exclude others from use, 3 ) earn income from use, and 4) dispose of the property. These basic rights are a foundation; after they are protected, a property's economic value depends on its characteristics and attributes. The right to exclude others from use is not directly related to the ability to use property for profit and is at times not strongly emphasized, although it is well-recognized (Demsetz 1967). This paper relies heavily on it. This right to exclude is especially pertinent for intellectual property and other intangible assets. Unauthorized use of intellectual property does not prevent its owner from using it, but it does prevent its owner from appropriating profits. The incentive to innovate depends upon the ability to appropriate returns from an asset, which is linked both to the strength of property rights and to the asset's characteristics. The property itself, once protected by strong property rights, must have a profit potential that cannot be trivially copied by another firm.

\subsection{Assets and market competition}

Porter (2008) defined five competitive forces that determine the strategies of individual firms. These include 1) the threat of entry, 2) bargaining power of suppliers, 3) bargaining power of consumers, 4) substitute products, and 5) rivalry of incumbent firms. The prevalence of each force affects all firms in an industry, but strategies for mitigating these forces are specific to each individual firm. A firm can attempt to undercut competitors' prices or produce higher quality goods. It can attempt to produce substitutes of a competitor's goods or carve out its own market by producing complements. Innovatively developing new, significantly improved products is another approach. Less benevolently, a firm can seek for state favors. All of these strategies, including rent seeking, have their roots in entrepreneurial discovery of asset price discrepancies as firms acquire, develop, or repurpose assets to improve returns.

Market structure and the market process are mutually linked. The entrepreneurial strategy of a firm is influenced by these competitive forces (determined by the market structure of the industry) and these strategies collectively define the industry's market structure. Market structures include perfect competition (persistent threat of entry, rivalry among firms, nearly identical products, no substitute products), monopoly or oligopoly (low bargaining power of consumers, no substitute products, minimal threat of entry), or monopolistic competition (widespread differentiated substitute products, persistent threat of entry).

The business environment is competitive regardless of market structure as long as entry and the exploitation of price discrepancies in geography or time are available. Firms' competitive strategies rely on assets perceived as underpriced given their potential over time, although the chosen strategy may be influenced by 
pricing perceptions affected by market structure. The most desirable assets are those that competitors not only do not have, but cannot easily copy. As these assets were not exploited until the first entrepreneur saw an opportunity, such assets are often underpriced unless subsequently sold. This scarcity can be physical in nature (real property in some locations), artificial or legal (intellectual property), or due to sound and successful business practices (trade secrets, corporate culture, business relationships).

Most sectors have examples of these assets. For retail trade, a firm can attempt to locate itself in a geographically desirable location where land is in limited supply. For manufacturing, firms can rely on trademarks and branding or on other unique aspects of their products which could be patented. Airlines can bid for scarce landing slots at crowded airports to gain a dominant position in a lucrative market.

When a particular type of asset exists that can be used to mitigate competitive pressures, such as scarce desirable land, airport landing slots, or protected intellectual property, firms naturally orient their business around it. Within these broad asset categories, particular assets with unique characteristics are used by individual firms. Property rights must be respected for this to be possible, but the asset itself needs some characteristic that allows its owner to use it for advantage over a competitor.

As firms collectively orient themselves around assets with long-term profit potential owing to non-replicable characteristics, industries become organized around particular types of property. For example, most medical innovation is oriented around patented drugs and devices, as opposed to new medical procedures, which are not protected. ${ }^{2}$ Oil extraction companies seek land and mineral rights in productive areas with high-quality oil. Retail stores seek plots of land at existing urban shopping centers as opposed to distant, rural areas where land is cheap and plentiful.

Not all strategies for mitigating competitive pressures rely on productive assets. The software and entertainment streaming industries mitigate competition by licensing their products without selling them, so as to retain considerable control. Other firms create in-house incentives to retain customers, such as product servicing (cloud-based software) or loyalty programs (airlines, hotels). These programs create valuable business relationships. Competitors can copy the programs, but consumers' switching costs can keep them from being lured away from existing relationships. As with other strategies for mitigating competition, namely exploiting productive assets or rent seeking, these strategies involve startup costs and yield benefits which may not have been noticed before, especially if nothing similar had yet been done.

Rent seeking, another strategy for mitigating competitive forces, refers to cronyist behavior directed toward the state that is designed to obtain rents and increase one's own wealth without creating new wealth or otherwise adding value (Krueger 1974; Tullock 1967). Rent seeking may result in state-protected monopolies or oligopolies such as those enjoyed by utilities, telephone companies, and internet service providers, or it could result in government subsidization as has happened with field crop agriculture in the United States. These non-productive

\footnotetext{
${ }^{2}$ Medical procedures may be patented, but the Omnibus Consolidated Appropriations Act of 1997 prohibited enforcement against physicians, leaving them essentially unprotected (Strandburg 2014).
} 
approaches to mitigating competition are still entrepreneurial to a degree (Holcombe 2002). Firms must weigh the costs of organizing the industry and hiring lobbying teams against their odds for success. Those that are first to succeed reap the benefits which, in the case of rent seeking, are a permanent advantage.

\section{Amimetic assets}

Firms in some industries rely heavily on productive assets to mitigate competitive pressures. Other industries are dominated by rent seeking. Even in rent seeking industries, businesses do use assets and their property rights are just as secure as those in industries that rely less on rent seeking. This section addresses the central question of the paper, namely "Why do firms in some industries innovate but firms in other industries consolidate and seek rents?

The answer lies in the newly-introduced concept of amimetic assets. The Greek word amimitos, the source word for amimetic, means "inimitable." Amimetic assets are unique in that they cannot easily be duplicated by another firm, so they have an exchange value premium in addition to utility value. This premium comes from impediments to duplication or appropriation by other firms. These impediments are scarcity of the assets and scarcity of their substitutes, which may come from the physical nature of the property, but also include legal protections for intellectual property including trade secrets, trademarks, patents, and copyrights. They can also include the time and unique effort to develop business relationships and implement business models.

In order to obtain or create an amimetic asset, a firm must correctly perceive that the asset has profit potential that has not yet been realized (arbitrage in time), resulting in a cost to obtain or develop it that is less than the returns it will yield over time. Sunk costs to create or obtain new amimetic assets are high and the process involves taking many risks. These costs and risks are one reason why earlier entrepreneurs did not perceive the opportunity and the arbitrage opportunity remained.

Amimetic assets, like all assets, exist and have value because property rights are protected by the legal system. Whether an amimetic asset is real, chattel, or intellectual property, it has its amimetic qualities because it is protected by law. Property rights must be defined and enforced for returns to be appropriated, but this is relevant only insofar as the asset can produce returns. The value premium of amimetic assets comes from to the fact that they can be utilized by a business to gain advantage over competitors who cannot easily duplicate it.

Hayek, in The Constitution of Liberty ([1960] 2011), discussed private property as an essential element in preventing coercion of individuals. He wrote, "In modern society, however, the essential requisite for the protection of the individual against coercion is not that he possess property but that the material means which enable him to pursue any plan of action should not be all in the exclusive control of one other agent." It is clear that just owning property does not preserve the agency of individuals, but their ability to act independently for their own good. Productive assets can facilitate this, but only if they have the right characteristics and the individual has a sufficient quantity. For businesses, the principle is the similar - assets must have non-replicable characteristics relevant for that business. 


\subsection{Sources of the value of amimetic assets}

Any asset has exchange value. Productive assets are discovered and created by entrepreneurs. The prior non-use or non-existence of these assets is a reflection of their subjectivism. Subjective valuation is a reason why the opportunity was not seized earlier. Others did not see it not because it did not exist, but because they perceived value differently. When the new asset is something that cannot be trivially copied, such as a patent, trade secret, successful business culture, business relationships, or scarce land in a particular area, it has profit potential that can endure in the face of competition.

The exchange value of amimetic assets may or may not result from any particular utility value. Some amimetic assets, such as trademarks, are valuable because they link a product with a certain producer, signaling quality. These intangible assets can be exchanged, but only with the accompanying business. Scarce land in a desirable commercial area is an example of an amimetic asset that has exchange value unrelated to any utility value. The intrinsic qualities of the land are not unique to that parcel. Land can have many physical characteristics and still be good for building a shopping center. Its value comes from scarcity of the desirable location; if a parcel is occupied, another building cannot be built there.

Patents are amimetic assets with both exchange and utility value. A patent has exchange value as the exclusive right to the utility value of producing a product or using a process that is better than alternatives. Natural resources may have a utility value premium or may only have exchange value. A firm may have an amimetic asset in a natural resource without having monopoly control over the entirety of that resource. An isolated oil field located near a refinery, but with mediocre oil quality, may command a premium due to its location. An oil well with very good oil near lots of other oil wells with inferior oil commands a premium because of its intrinsic attributes. Either provides a competitive advantage to the firm that owns it, but for different reasons.

The impediments to duplication and appropriation that characterize amimetic assets are not insurmountable; amimetic assets do not necessarily confer monopoly power, especially over long time horizons. Moreover, as I demonstrate in section 4.3, it is a lack of amimetic assets that leads to monopoly, not possession of a sufficient quantity of them by a firm. Holcombe (2003) writes that entrepreneurial success creates new entrepreneurial opportunities. When an entrepreneur successfully obtains or creates amimetic assets, new and similar, but still unexploited, profit opportunities become more noticeable. A company can seek to establish a comparable advantage through patenting a distinct yet similar technology. Likewise, a retailer can attempt to build a new shopping center in a new, undeveloped area and hope that subsequent development makes the initial development more unique and desirable, something that frequently happens with outlet malls on the outskirts of urban areas. Once new amimetic assets are created, they yield a new amimetic advantage, distinct from the amimetic assets of competitors.

Amimetic assets are not easy or trivial to create, but once created, their value cannot be appropriated by a competitor; at best, a competitor can create a distinct, comparable advantage. For example, a pharmaceutical company can respond to a competitor's proprietary drug with a new drug to treat the same illness, although this likely will not 
take all of the first drug's market share. Profits from amimetic assets persist even under entrepreneurial competition because of their non-replicable advantages. Because creation of similar and competing amimetic assets is possible, it fosters competition, not monopoly, despite persistent profits. The defining characteristic of amimetic assets is that they cannot easily be duplicated or appropriated by a competitor, but obtaining a similar, but very distinct amimetic asset, must be possible. Profits from amimetic assets will not be competed away by other entrepreneurs who attempt to imitate the first mover; they are eroded only when another entrepreneur creates superior amimetic assets, which is generally not a quick or easy process. If a later entrepreneur's advantage is distinct enough, it still may not completely diminish the first entrepreneurs profits.

\subsection{Examples of amimetic assets}

Airplanes, ground facilities, and labor contracts do not vary much across airlines and are not amimetic assets. Landing slots and terminal space at crowded airports are amimetic assets. Airlines may even lease more terminal space than they need just to keep competitors from using it. Airlines' amimetic assets mostly have exchange value because they often lack intrinsic attributes that make one airline's product better than others. Rather, their amimetic assets have value because of scarcity in a zero-sum game. If one airline has a landing slot, another cannot use it.

This artificial scarcity was once the only real source of amimetic assets for airlines. However, new amimetic assets are a product of discovery of what was once unnoticed. In the United States, Southwest Airlines rose above larger competitors to profitability with a unique business model intertwined with a culture that was built over time that is not easily duplicated. Some industries may seem to have little potential for the development of amimetic assets, but this may not be true forever; amimetic assets are created by the entrepreneur who successfully exploits what had been unnoticed or ignored.

Business relationships, as well as successful corporate cultures like that of Southwest Airlines, are amimetic assets. In most cases, they are not protected by law like real or intellectual property are, but in some cases contract law (e.g. non-compete clauses) can serve an equivalent purpose. These business relationships, which could be with clients, suppliers, or related industries, have the characteristics of amimetic assets as they cannot be trivially duplicated.

Oil production is another example of a sector in which some industries have more amimetic assets than others. Firms that extract oil need land or mineral rights at desired oil fields which are geographically fixed and command a premium over aging fields or those with heavier oil. Such real assets have special value and are scarce in supply, so they are amimetic assets. The refining stage is different. Refineries can be built wherever oil can be shipped and may be located close to major population centers away from oil fields. Refineries are not amimetic assets because a similar refinery can be built elsewhere, unless prevented by regulatory barriers. A parcel of land may be an amimetic asset for a refiner if it is close to ports or pipeline terminals, but the refinery itself is not an amimetic asset.

Amimetic assets for software companies include trade secrets, patents, and client relationships in the case of cloud-based software as a service (SaaS). The enforceability 
of software patents is not guaranteed in the United States (Tran 2016), although they frequently are upheld. Copyrights do not make amimetic assets out of software because they only protect source code, not functionality, which can be duplicated without infringing the copyright. Trade secrets, which are amimetic assets for many sectors, do not always provide useful protection for software because it can be reverse engineered. This uncertainty places software between the extremes of the very unique investment that is amimetic assets and something common and easily duplicable and explains the industry's reliance on product licensing to effectively create amimetic assets.

A particular amimetic asset not only provides an advantage to the business that owns it, it also provides incentives that direct the competitive strategy of firms that do not own it. Firms should attempt to find their own competitive advantage that is uniquely different from their competitors. If no incumbent firm in a desirable shopping center is willing to sell its storefront, a firm can invest in a completely new shopping center and attempt to make it attractive to consumers. A continual cycle of this was modelled by Reinganum (1985), who pointed out that the monopoly profits from an innovation (or amimetic assets) only last until a more innovative firm obtains a better, distinct advantage. A patent requires public disclosure of the invention and is (or should be) fairly narrowly defined. A firm that does not hold a patent for a sought-after product has a clear incentive to invest in research and development to produce a substitute or improvement and obtain its own advantage. Even obtaining a distinct advantage may not fully capture profits of the earlier entrepreneur, whose customers may not always prefer something materially different. For example, building a new outlet mall on the edge of a city may attract both new customers as well as some existing customers of a citycenter shopping mall, but it won't take all of the existing mall's customers.

An amimetic asset for one industry may lack these qualities in another. For example, a desirable plot of land in a high-traffic urban location is an amimetic asset for a retail trade business, restaurant, or hotel. However, land for building a consumer goods factory is not an amimetic asset because it does not need proximity to concentrated urban traffic. A copyright is an amimetic asset for a book publisher or digital entertainment company, but not for a software developer.

A business in a supplying or purchasing industry may itself be an amimetic asset for a firm. Vertically integrating by acquiring such a business may provide efficiency advantages over its competitors. It may prevent consolidation in the acquired firm's industry and thus ease this competitive force (Colangelo 1995).

Zoning laws can create opportunities to discover amimetic assets and simultaneously eliminate those that once existed. By restricting one use of land to a specific area, parcels in that area take on the value premium of an amimetic asset. By not permitting development in others, they prevent attempts to create new amimetic assets. They promote oligopoly rather than dynamic competition. Zoning laws can be the target of rent seeking efforts.

Regulatory barriers to economic activity are a result of rent seeking and are not amimetic assets; they are a restriction on the use of property. If a property's value premium is because of overreaching regulations, it is not an amimetic asset because it is not possible to obtain a distinct, yet comparable advantage from other property; these rents cannot be competed away. The critical difference between amimetic assets and 
beneficial regulatory barriers is that amimetic assets encourage further entrepreneurial innovation, but regulatory barriers stifle it.

All property is defined by government to some degree. Real property is defined by invisible lines demarcating boundaries. Patents are defined by unique claims. The line where government rules become overbearing and prevent the use of property instead of creating amimetic assets is subjective.

\subsection{Distinction from asset specificity}

Amimetic assets are similar to, but distinct from, the concept of asset specificity, a concept for which a well-developed literature exists (Riordan and Williamson 1985). Asset specificity is defined as the extent to which investments made to support a particular transaction have a higher value for that transaction than they would have if redeployed for any other purpose. If specific assets cannot be redeployed for another purpose or if an outsider would have difficulty in learning to use them, they certainly are amimetic assets. Likewise, transaction-specific human investments like employee training or business model improvement may be amimetic assets. Because of the unique qualities of amimetic assets, they are often specific assets as well, especially if they are intangible assets, have much utility value, or require specialized knowledge or skills to use.

Although amimetic assets often are specific assets, specific assets do not automatically equate to amimetic assets. It may not be possible to repurpose a factory to serve another purpose, making it a specific asset; however, if a similar factory can be built nearby, it is not an amimetic asset. Likewise, a valuable storefront in a high-traffic could be used just as well by a competitor selling very different goods. Repurposing it does not decrease its value, so it is not a specific asset, but it is an amimetic asset due to its location. The unique, non-replicable advantage that characterizes an amimetic asset may not be specific to a particular transaction.

\section{Amimetic assets in a capitalist system}

Entrepreneurial profits require superior alertness to arbitrage opportunities. Frequently, these opportunities exist because the potential for an asset was not noticed either because it had not been repurposed or had not been created. The costs to obtain or create a new asset, especially a new amimetic asset, are high and often uncertain. Returns are uncertain as well.

Amimetic assets are key to satisfying consumer demand because they result in better or more accessible goods or services. If the new products or services are sufficiently differentiated and preferred more strongly by consumers than alternatives, amimetic assets can help a company displace incumbent competitors. This is the familiar process of creative destruction that is well-known in capitalist systems (Schumpeter 1943). Rather than being a disequilibrating force, it is a result of disequilibrium as shown by the fact that the arbitrage opportunity led to this "destruction."

One entrepreneur's success leads others to compete by doing the same or similar things. The price of the new output may decrease, or the price of the productive asset may rise, or both. If the productive asset has the non-replicable characteristics 
of amimetic assets, profits persist and this equilibration will not occur because such a non-replicable asset is not widely traded, although a firm can choose to sell it to another that values it differently. This fact highlights the valuable characteristics of amimetic assets. Successive entrepreneurs must find their own unique advantage from a yet-unseen arbitrage opportunity.

The nature of amimetic assets leads to long run profits for the entrepreneur, even though the market is competitive. As the entrepreneurial process of competition unfolds with time, these profits may disappear if other entrepreneurs successfully develop or obtain new amimetic assets as they correctly perceive arbitrage opportunities (Kirzner [1973] 2013). They will not, however, be competed away by other firms copying the innovative entrepreneur, whose unique advantage they cannot obtain. Only subsequent success in creating and utilizing amimetic assets will reduce the profits of once-successful entrepreneurs.

Consider differentiated consumer products that are protected by undisclosed trade secrets with distinct branding that is protected by trademark law. The goods may not differ much across manufacturers, but the branding and appearance may not be copied. It has value if the firm's product has market loyalty. The trade secrets are intangible amimetic assets. The trademark is also an amimetic asset that increases the value of the trade secrets. Because they affect the returns a prospective entrepreneur can earn, they deter entry, although entry is still possible. As a result, some of Porter's other forces availability of substitutes, rivalry of competitors, and bargaining power of consumers are mitigated as well, but bargaining power of suppliers may be exacerbated.

Lee et al. (2000), studying the advantages of being the first to bring a product to market, find that the first mover (first to spot a profit opportunity) does have an advantage in profitability. They examine the brewing, long-distance telephone, and personal computer industries from 1975 to 1990 when they became more competitive. Although they do not describe the types of property these industries use in production, they do find a significant positive effect in being the first to market for the long-distance telephone industry, which has considerably more amimetic assets than the other two. This supports the view of amimetic assets as the key to long-term profitability after successful entrepreneurial discovery.

Amimetic assets may appear anticompetitive because they are not observed under perfect price competition. They find their role in somewhat more concentrated markets. Regardless of market structure, innovation will not suffer if entry and entrepreneurial discovery are possible. Large incumbents have an incentive to innovate even in a highly concentrated market. Their failure to do so, which Christensen (1997) notes, is largely due to new, small competitors having superior alertness to opportunities. This explains the general consensus in the literature that innovation thrives in an environment that is neither perfectly competitive nor monopolized, but somewhere in between. In a perfectly competitive environment, arbitrage opportunities may be scant, even over time, but they could still arise and be noticed. Conversely, monopolies are often statesupported, and entrepreneurship may be stifled by regulatory barriers.

\subsection{Consolidation in the absence of amimetic assets}

When amimetic assets are not prevalent in an industry, the lack of long-run profits can lead to price competition and consolidation. Entrepreneurial discovery need not be 
hindered and, if price competition is to exist, there must be the possibility of entry. Larger firms tend to fare better in an environment of price competition. When a smaller competitor seizes a profit opportunity that had not been noticed, the larger firm can be a "fast second" and quickly copy the first mover's successful innovation (Baldwin and Childs 1969). This happens only if the arbitrage opportunity did not involve amimetic assets for the entrepreneur.

The ability of large firms to succeed under price competition is an incentive for consolidation to mitigate the competitive forces Porter identified. Consumer prices may not increase but there also may not be much innovation. Entrepreneurial discovery requires that expected profits exceed expected costs. If the industry is characterized by a lack of amimetic assets, expected profits are smaller and there are fewer existing profits to use for investment. Innovation and entry are thus possible and arbitrage opportunities may exist, but prospective entrepreneurs will be less likely to act on them and they may be harder to perceive. Consumers suffer from the lack of innovation, not from high prices.

Some industries that lack amimetic assets and historically have not been concentrated have recently become more consolidated. Farms, with their lack of amimetic assets, have consolidated and grown in size in recent decades, but are not oligopolistic (MacDonald and Hoppe 2017, 2018). This is likely due to changes in cost structure from productivity gains, ${ }^{3}$ but if there had been some form of amimetic assets, it could have enabled smaller farms to compete rather than consolidate.

\subsection{Rent-Seeking and state intervention}

Large firms not only take on market power but also political power. Consolidation, even if it is a result of price cutting that benefits consumers, has its drawbacks. They tend to lobby for protection or rules that can bring prices up or erect barriers to entry. Stigler (1971) developed the capture theory of regulation in which firms seek for regulation for their own benefit to harm competitors, an idea complemented by Olson (1965) and Posner (1974). Holcombe (2018) described a collusive system between large businesses and the government as a distinct economic system known as "political capitalism."

Many factors influence a firm's decision to seek regulation, including the perceived lack potential for obtaining amimetic assets, as explained above. Others include costs of organizing the industry for lobbying, direct costs of lobbying, costs of indirectly influencing and publicly promoting legislation, and other costs of accumulating political power over time. These costs may be easier for large firms to bear. Moreover, things like acquiring political power may be a function of size, so the costs to consolidate and organize are the costs to acquire political power. When this is the case, consolidation is directly linked to rent seeking. All of these costs must be weighed against the benefit from regulation, which may also depend on size, thus influencing consolidation decisions. Comparing these expected costs and benefits is part of the entrepreneurial process but, instead of

\footnotetext{
${ }^{3}$ DePillis, Lydia "Farms Are Gigantic Now. Even the 'Family-Owned' Ones.” Washington Post, August 11, $2013 \mathrm{https} / /$ www.washingtonpost.com/news/wonk/wp/2013/08/11/farms-are-gigantic-now-even-the-familyowned-ones/, accessed 23 October 2018.
} 
focusing on productive assets, the focus is on nonproductive political assets (regulatory rents) that stifle productive entrepreneurship.

The consolidation and rent seeking that result from a lack of amimetic assets are linked problems. A lack of amimetic assets makes price competition and eventual consolidation more likely, although other factors also affect it. This in turn makes rent seeking more attractive and feasible. Observers on both the political left and right have observed this phenomenon of businesses seeking for government policies to further their interest and that large, dominant businesses are most successful at it (Stiglitz 2012; Stockman 2013).

Consolidation is a prudent investment when amimetic assets are difficult to obtain, although it could make sense for other reasons. Although amimetic assets may not always prevent the consolidation that ultimately leads to rent seeking, the incentives to consolidate and lobby are greater without it. If the other factors that influence the decision to seek rents are low enough compared to expected benefits, rent seeking could still result. In this regard, amimetic assets can be a hedge against forces that cause the free market to degenerate, but not a guarantee.

This role of amimetic assets in mitigating the incentives for rent seeking and state intervention is its most important role in a capitalist system. Entrepreneurial competition is possible in any sector with or without them, but amimetic assets offer persistent profits that make the market process attractive. Without amimetic assets, rent seeking is far more appealing because it offers profits that are more persistent than those offered by entrepreneurial competition.

Large corporate size in a static sense is not detrimental; its harm is in the ability to successfully seek rents and impede the entrepreneurial process. Insofar as large size is detrimental, the American paradigm of antitrust law, which focuses on consumer welfare as opposed to competition among firms, provides little in the way of a useful remedy.

\subsection{Natural monopoly and its "Natural" incentive}

Textbook definitions of natural monopoly consider the phenomenon to be a result of a cost structure in which average production costs decline as quantity of output increases, most often due to high fixed costs (Baumol 1977; Sharkey 1982). Classic examples of natural monopoly industries include electric power generation and distribution, landline telephone service, and internet service. Firms in these industries are local monopolies only because of government regulation. These industries were not always monopolized (DiLorenzo 1996). There is no evidence that these natural monopoly industries formed monopolies and charged high monopoly prices without government regulation (Demsetz 1968).

Common to these so-called natural monopoly industries is a general lack of amimetic assets. ${ }^{4}$ It is possible to establish competing enterprises in any of these industries in the absence of regulatory barriers and this used to be common. The expected costs and benefits of seeking to become a regulated monopoly are influenced by the presence or absence of amimetic assets. Without them, long term profits are

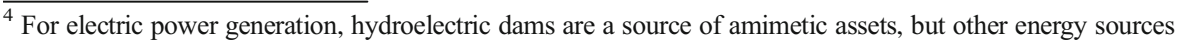
often are not.
} 
lower as asset prices adjust. The relative benefit of regulation over competition based on productive assets becomes higher. As a result, it becomes more appealing to incur the costs to consolidate or organize the industry and lobby than to invest in productive assets. Natural monopoly is thus not a result of the structure of costs of production, but of the natural incentives to seek regulation that are influenced by the lack of amimetic assets. Most monopolies are in these industries that lack amimetic assets. Temporary monopolies may result from control over resource ownership, but permanent monopolies result from state intervention when amimetic assets are nonexistent or harder to obtain than state favors.

Schumpeter (1943) believed that capitalism is not sustainable and eventually would be replaced by socialism. His reasoning centered on the fact that capitalists and capitalism would nourish an intellectual class and public sentiment that would eventually undermine the innovative system. This paper's theory of amimetic assets also outlines how a capitalist system can degenerate, but the reason is very different and the extent of the demise of capitalism will vary by industry.

Capitalism has not degenerated into socialism in most industrialized western countries. Rather, state-sanctioned monopolies or oligopolies or other forms of noncompetitive markets have emerged. Monopolies, oligopolies, and state intervention in the economy are expected results of a lack of amimetic assets. It is important to note that the free market system may be undermined in some, but not all sectors, depending on the prevalence of amimetic assets in each. There need not be a general decline of free, capitalist markets throughout the economy.

\section{Examples and empirics}

AT\&T is one of the best examples of an innovative company that subsequently consolidated, ceased innovating, and successfully sought regulatory rents. It rose to prominence with an innovative product, the telephone, that was an amimetic asset because of a patent. Through some unethical business practices, it grew in size with a mixture of integration, consolidation, and predatory pricing to harm obstinate competitors. This was possible because its long-distance network was an amimetic asset. By the time it had amassed a nationwide network, the innovation had long since stopped.

Once the telephone system was in place, antitrust concerns at the Justice Department became louder and the pace of innovation and obtaining new amimetic assets seemed slow. Rather than fight, AT\&T turned to overt rent seeking and became a stateregulated monopoly, arguably the strongest possible result from rent seeking behavior. It ruthlessly suppressed innovation, both in-house and by third parties, out of fear that its position could be undermined should a competitor be able to use any of its innovations (Wu 2010). The predatory pricing that fueled its expansion would have been good for consumers had a state monopoly not resulted.

Competitors and prospective competitors were harmed not by AT\&T's large size, but by regulatory prohibitions on entry and production of innovative new equipment. AT\&T was ultimately broken up in an antitrust lawsuit after many decades, although permitted competition had already begun to eat away at AT\&T's business, notably by an innovative, entrepreneurial MCI Communications. Prior to 
the breakup, it had survived primarily because the federal government prevented competition from materializing.

Amimetic assets can be hard to observe and difficult to measure. Holding all else constant, both amimetic assets and rent seeking behavior increase demand for a firm's output and increase profit. In order to measure amimetic assets, the sources of these increases must be distinguished from each other. Research and development spending represents innovative effort, but not outcomes; it reflects a perception of an unexploited profit opportunity. Profits are likely to be higher in areas where outcomes of research and development are protected from competitors, or where successful research and development results in amimetic assets.

Measurable outcomes of research and development, such as the number of patents, can be even less informative than spending in this regard. Trade secrets, which are very valuable amimetic assets, are not observed, unlike patents. R\&D spending does account for attempts to create new trade secrets. Moreover, the number of patents a firm has disregards the fact that a patent could turn out ex post to be useless.

Table 1 contains data from the National Science Foundation on R\&D spending by NAICS industry sector. The right-most column has R\&D spending as a percent of sales by companies in a given industry that undertook research and development in-house. The adjacent column to the left includes only sales of companies that paid a third party to conduct R\&D.

Sectors with strong intellectual property rights tend to have the most R\&D. Pharmaceutical companies spend $17 \%$ of sales revenue on R\&D. Semiconductor machinery companies spend $25.7 \%$ and semiconductor computer products companies spend $14.6 \%$. Industries with weaker protections for innovation have substantially less $\mathrm{R} \& \mathrm{D}$, such as wholesale trade $(0.2 \%)$ and petroleum and coal products manufacturing $(0.1 \%)$. Utilities, which tend to be state-protected monopolies, engage in very little R\&D, at only $0.2 \%$ of sales.

Because amimetic assets affect profitability, businesses with more of them should have higher stock prices. Forbes magazine ranks the world's most innovative large companies ${ }^{5}$ by comparing market capitalization to net present value of cash flows (NPV, measured using a proprietary algorithm from Credit Suisse). The excess of market capitalization over NPV, expressed as a percent of NPV, is a company's "innovation premium" because, according to Forbes, the excess must be due to what the market perceives as a company's innovative potential. Presumably, the higher market value is due to the ability to reap persistent returns from innovation, which requires amimetic assets because profits would otherwise be competed away. Forbes omits from its rankings any company involved in mining or fossil fuels because these firms have market values more closely tied to commodities markets. Not all companies on this list are known innovators, implying that something else is likely driving these high valuations.

Innovation can produce profits from amimetic assets, but rent seeking can produce profits through regulatory rents. In order to judge which companies have the most amimetic assets, I adjust this Forbes index to correct for lobbying spending, which proxies for rent seeking. I only include the 51 U.S.-based companies on this list because OpenSecrets, which provides lobbying spending data, only provides U.S. lobbying

\footnotetext{
$\overline{5}$ https://www.forbes.com/innovative-companies/list/, accessed 31 December 2018
} 


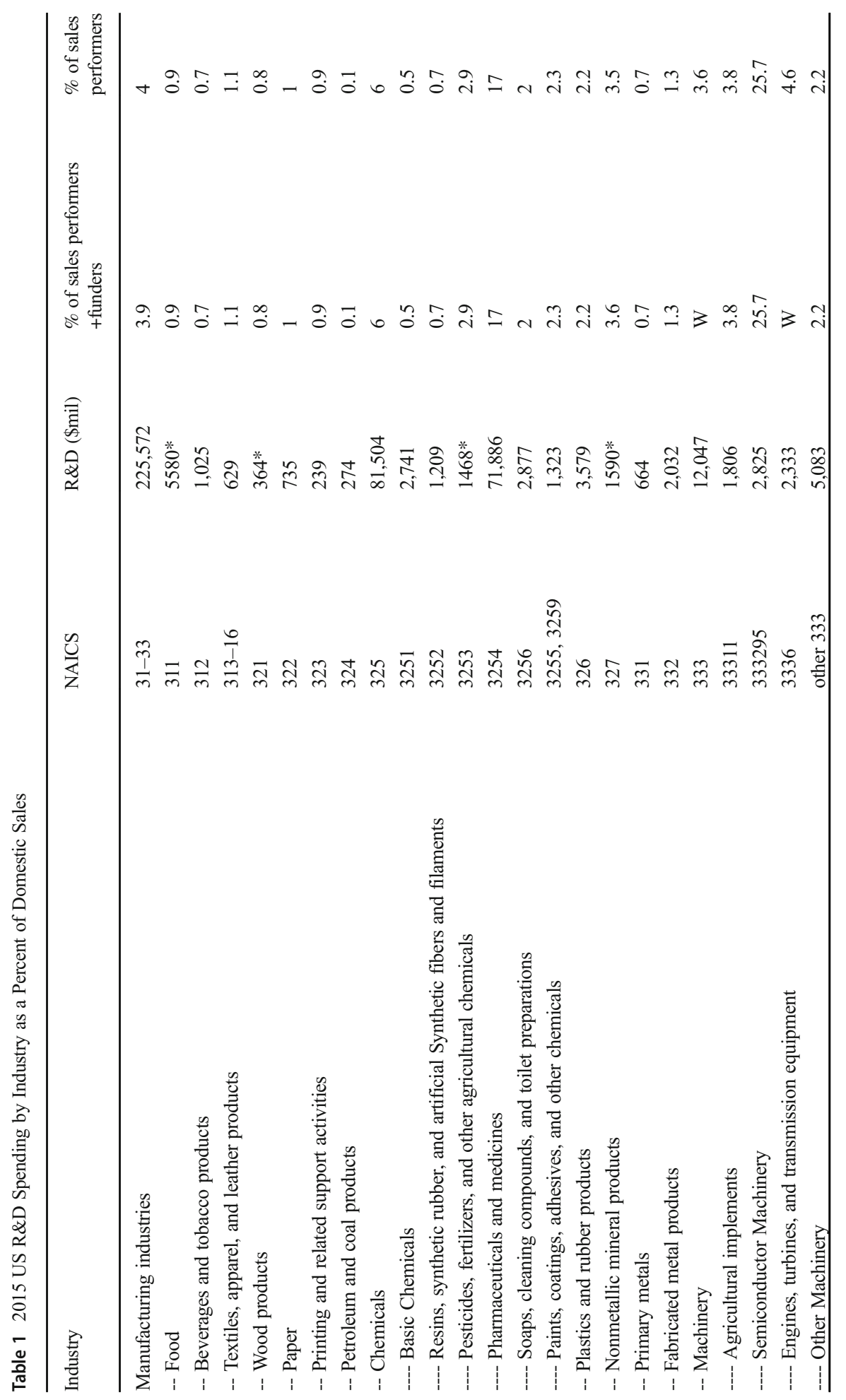




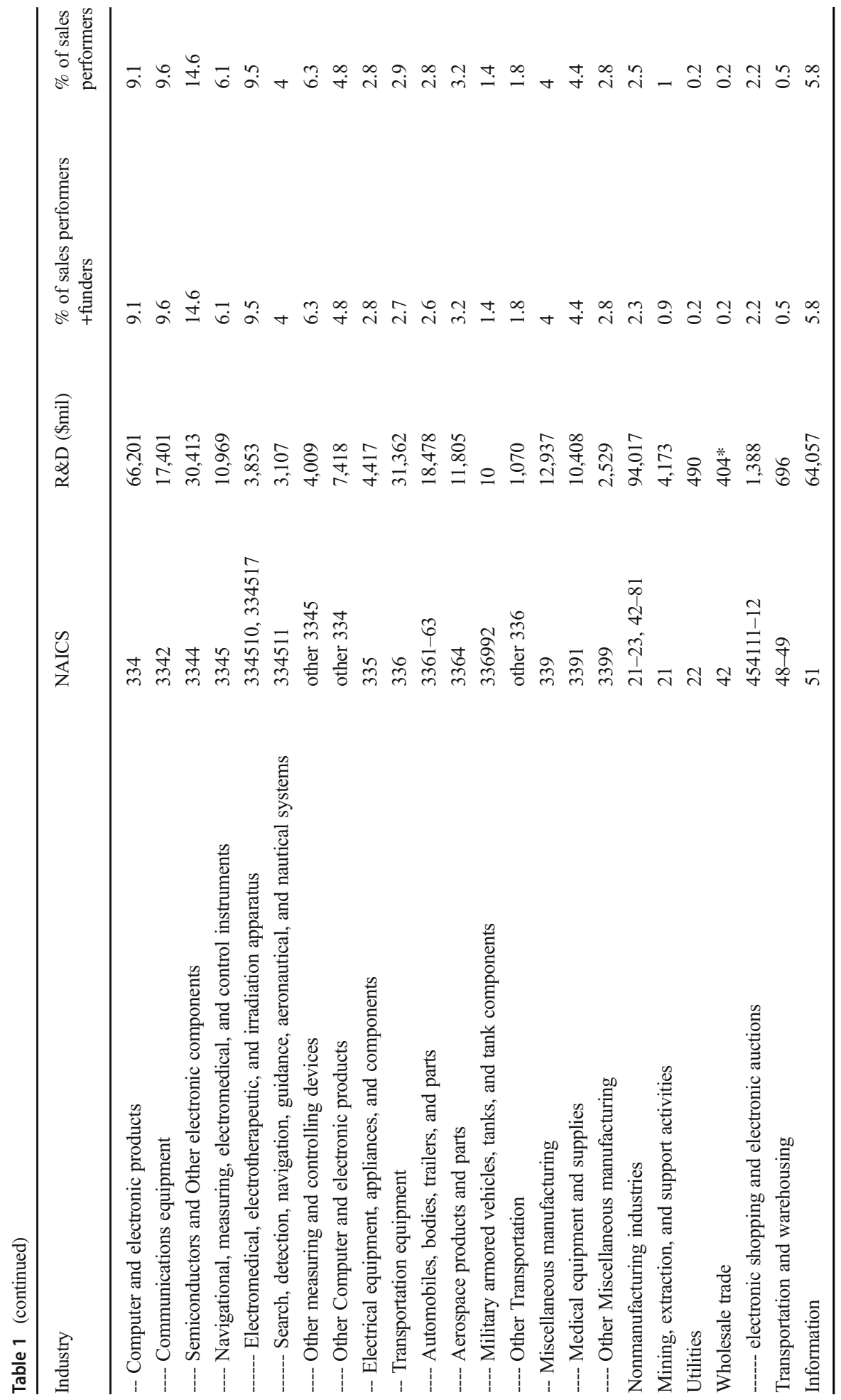




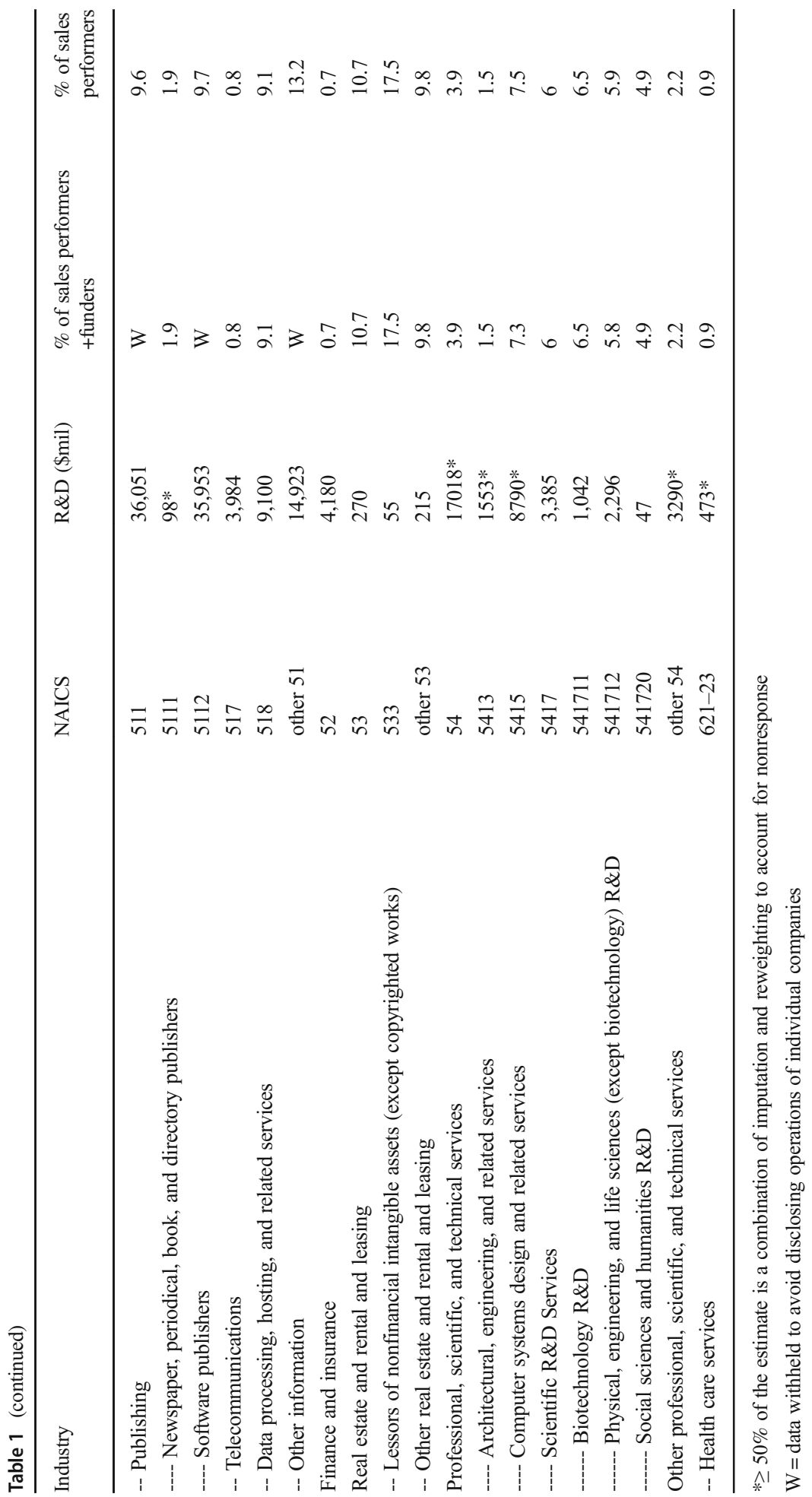


data. The Forbes list includes companies with market capitalizations in the billions of dollars (from $\$ 15$ billion to $\$ 725$ billion), but lobbying ranges from zero to several million, never exceeding $\$ 18.37$ million. To adjust the innovation premium, I first calculate lobbying spending as a percentage of market capitalization and multiply this figure by 10,000 so as to make for meaningful readjustment of the index. The average of this result is 0.21 and exceeds one only for one firm. I then reduce the Forbes innovation premium by multiplying the innovation premium by this percentage. For example, if a firm's innovation premium is $40 \%$ amount, and rescaled lobbying as a percentage of market capitalization is $20 \%$, the adjusted innovation premium is $32 \%(40 \% \times(1-0.8))$.

Table 2 displays the results, including the companies on the list. Lobbying spending figures are totals for 2017, the most recent complete year available, which also corresponds most closely in time to the figures used in calculating the Forbes index. I also include each company's market capitalization at the end of 2018 to give an idea of the size of these companies and their subsequent growth.

Each company on this list has some clear type of amimetic asset. Incyte, which increased in the adjusted ranking, has marketed only one drug in the United States and one different drug in Europe, according to its web site, but it has an extensive research portfolio, the contents of which can be protected by patents. Many companies on this list protect their amimetic assets through trade secrets, trademarks, and branding and these intangibles are one of the most prevalent types of amimetic assets on this list. For some, amimetic assets are business relationships that can be protected through good service and continued innovation. Some companies on the Forbes list are not known to be innovative. Republic Services, a garbage collection company, ranked fiftieth, but jumped to thirty-sixth on the adjusted ranking. Its disposal facilities (transfer stations, landfills, treatment facilities) are a weak form of amimetic asset. Marriott International's profitability and value is likely due more to locations of its properties, which are a type of amimetic asset obtained through successful entrepreneurial discovery, but are unrelated to technological innovation.

Several companies plummeted sharply when correcting for lobbying spending. Facebook slipped nine places, which could possibly reflect the attention is has received for issues such as user privacy and facilitation of election interference, mitigation of which may have necessitated lobbying spending. Google, which increased in the rankings, does a tremendous amount of lobbying, although its market capitalization is larger than any other company on the list. Its increase is presumably due to the sharp declines of other companies.

Pharmaceutical and medical device companies are an interesting lot. Some of them increased in this adjusted innovation premium ranking (Incyte, Illumina, Intuitive Surgical), but others declined (Regeneron Pharmaceuticals, Vertex Pharmaceuticals, Edwards Lifesciences, Alexion Pharmaceuticals). Pharmaceutical companies, despite having patent portfolios consisting of valuable amimetic assets, engage in much rent seeking due to the highly regulated nature of the industry. Getting a drug approved by the FDA is one thing but getting Medicare to reimburse it is quite another. This is critical to the profitability of many drugs and requires lobbying.

AmerisourceBergen, a generic drug manufacturer and distributor, declined more than any other company in this adjusted ranking. Generic drugs have far less protection 


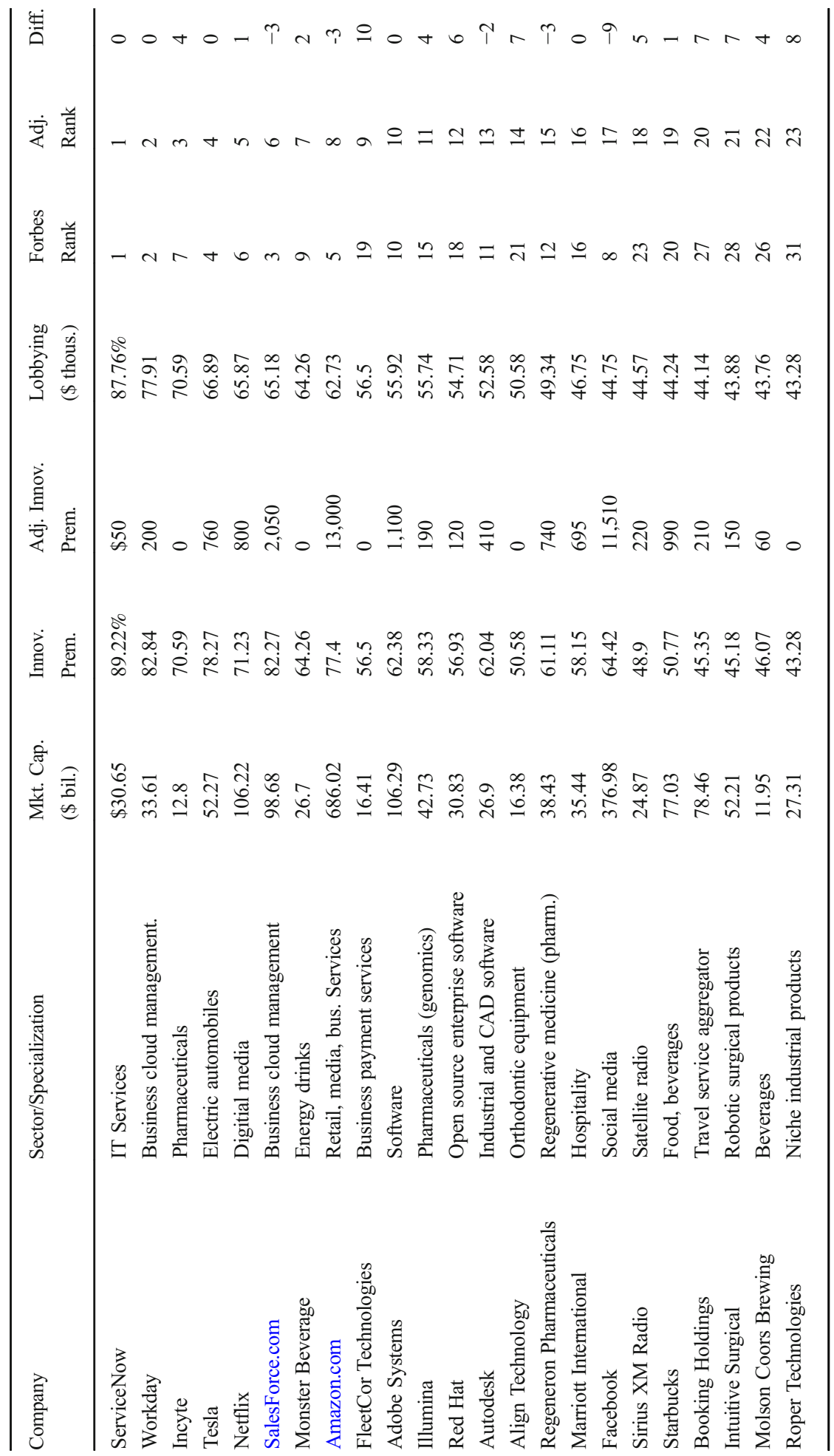




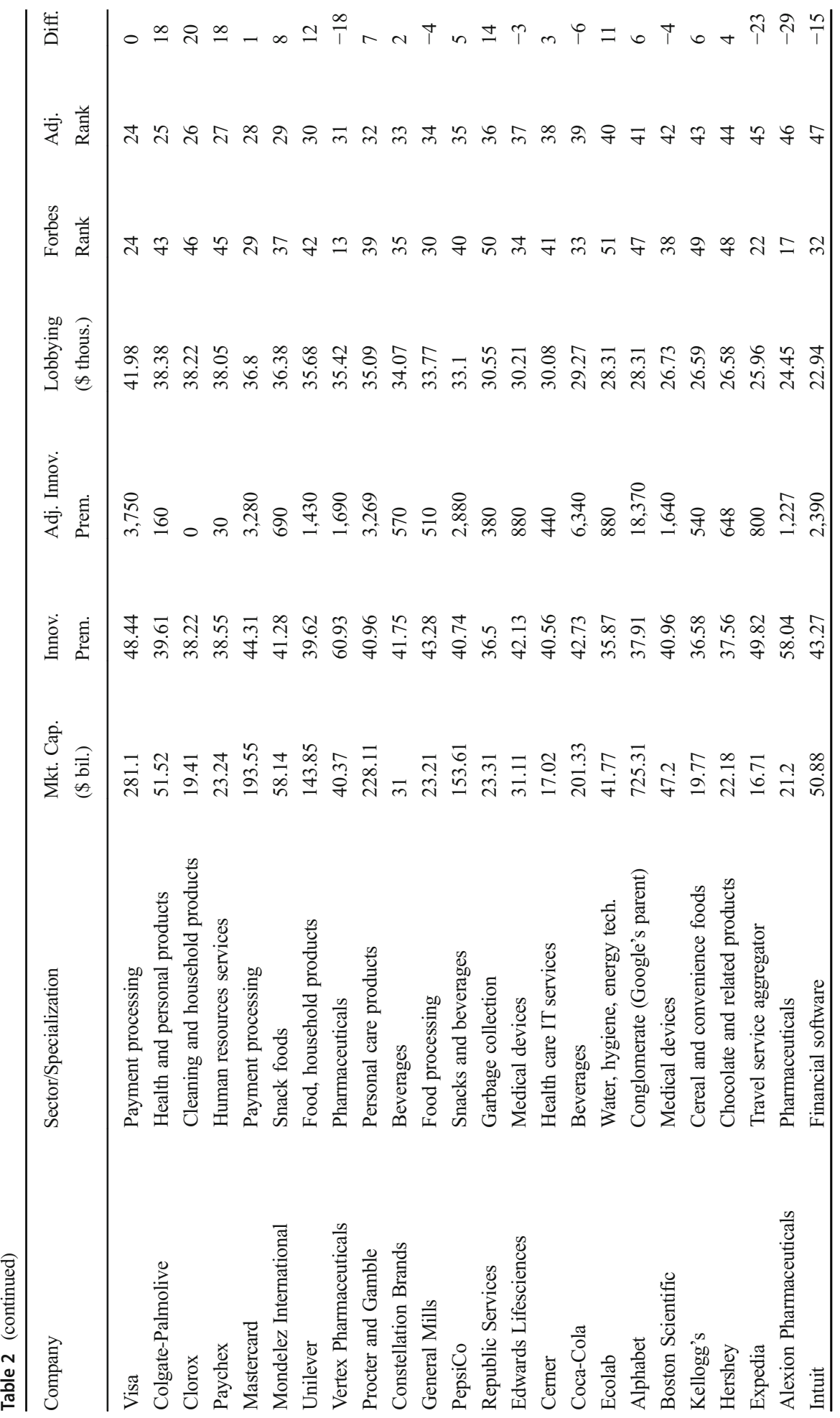




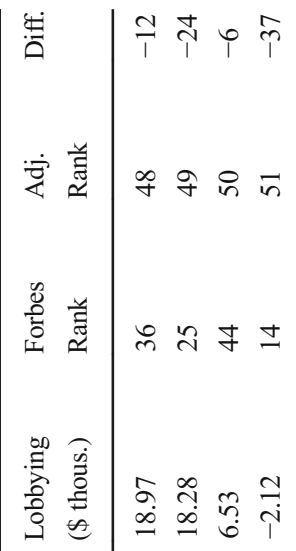

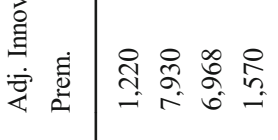

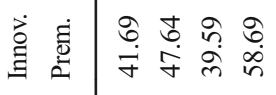

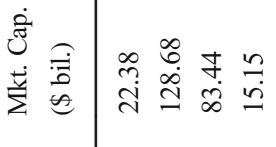

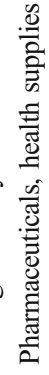

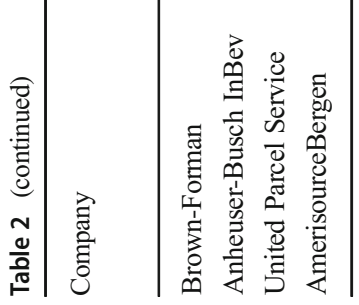

照 Springer 
from competitors than patented drugs, so AmerisourceBergen naturally has fewer opportunities to acquire amimetic assets.

The absence of any company from this list does not imply a lack of innovation or amimetic assets; it simply means that the market does not believe that the company has assets that will yield profits beyond what is accounted for by the net present value of current cash flows.

Apple, frequently thought of as an innovator, is absent from this list, although its products are protected by intellectual property rights. In 2018, most of the products it introduced were new versions of old products. Its only new product was the HomePod, a smart home device like Amazon's Alexa or Google's GoogleHome. Nothing groundbreaking was brought forward, and its market even declined somewhat, something of which investors have taken note. ${ }^{6}$ The value of Apple comes from its closed ecosystem and its products' ability to seamlessly work with other products, which are amimetic assets but, like all amimetic assets, can still lose value due to successful innovation by competitors.

\section{Conclusion}

This paper answers the question of why firms in some industries innovate but other industries are known for consolidation and lobbying for regulatory rents and state favors.

The profit motive is linked to property rights, specifically the right to exclude. Any profit-seeking business needs a revenue stream that cannot readily be taken by a competitor. Any business asset facilitates such a revenue stream if it is unique enough that a competitor cannot take it or trivially duplicate it. This is the concept of amimetic assets, derived from the Greek word amimitos which means "inimitable." Amimetic assets are defined by profit potential that cannot be trivially copied and lacks readily available close substitutes. Examples include scarce land at a desirable shopping center, a patented drug, established business relationships, and trade secrets. Amimetic assets are obtained through the entrepreneurial process as price discrepancies are noticed by alert entrepreneurs, just like any other profit potential. They differ from other assets because their non-replicable characteristics prevent market competition from subsequently eroding these profits which persist even without monopoly power.

When amimetic assets prove difficult to obtain in an industry, firms have greater incentive to consolidate and seek regulatory rents because these strategies for earning profits are become more cost effective. Entrepreneurial effort is thus diverted away from productive activities toward nonproductive political activity. Successful rent seeking makes it more difficult for other firms to enter and compete, blocking future entrepreneurial effort. In extreme cases, rent seeking could result in a protected monopoly, as has been the case for public utilities and even large companies such as AT\&T. Amimetic assets hedge against harmful consolidation and rent seeking but may not completely forestall it. An empirical analysis using lobbying spending figures and the Forbes innovation premium shows that companies that have more amimetic assets

\footnotetext{
${ }^{6}$ Kelly, Gordon. “Apple Warned iPhone Sales Are in Trouble” Forbes. 1 January 2019. https://www.forbes. com/sites/gordonkelly/2019/01/01/apple-iphone-xs-max-xr-upgrade-price-cost-sale-new-iphone-8/\#2959901 deeed, accessed 7 January 2019
} 
tend have stock that trades at a premium because of innovation as opposed to rent seeking, both of which can increase profits.

Amimetic assets exist because of non-replicable characteristics, but they are protected by a regime of property rights. Property rights always must be secure for amimetic assets to have value, but its ability to mitigate rent seeking incentives depends on its attributes separate from property rights. Property is important because of what it protects. Unique, investment opportunities must be protected as property if property rights are to do their job in sustaining a competitive, innovative economy. Property rights are valuable for economic growth only insofar as property, or business assets, actually facilitates this growth.

Acknowledgements I am grateful to Matthew Chervenak, Joseph Kochanek, and Nicholas Harlan of the Sunwater Institute, Randall Holcombe of Florida State University, and an anonymous referee for helpful comments to sharpen the analysis and broaden the application of this paper.

Open Access This article is distributed under the terms of the Creative Commons Attribution 4.0 International License (http://creativecommons.org/licenses/by/4.0/), which permits unrestricted use, distribution, and reproduction in any medium, provided you give appropriate credit to the original author(s) and the source, provide a link to the Creative Commons license, and indicate if changes were made.

\section{References}

Baldwin, W. L., \& Childs, G. L. (1969). The fast second and rivalry in Research and Development. Southern Economic Journal, 36(1), 18-24.

Baumol, W. J. (1977). On the proper cost tests for natural monopoly in a multiproduct industry. The American Economic Review, 67(5), 809-822.

Christensen, C. M. (1997). The Innovator's Dilemma. Cambridge: Harvard Business Review Press.

Colangelo, G. (1995). Vertical vs. horizontal integration: Pre-Emptive merging. The Journal of Industrial Economics, 43(3), 323-337.

Demsetz, H. (1967). Toward a theory of property rights. The American Economic Review, 57(2), 347-349.

Demsetz, H. (1968). Why regulate utilities? Journal of Law and Economics, 11(1), 55-65.

DiLorenzo, T. J. (1996). The myth of natural monopoly. The Review of Austrian Economics, 9(2), 43-58.

Hayek, Friedrich A. (2011) The Constitution of Liberty. The Definitive Edition, Ed. Ronald Hamowy. Chicago: University of Chicago Press, (Original published in 1960).

Hodgson, G. M. (2015). Much of the 'economics of property rights' devalues property and legal rights. Journal of Institutional Economics, 11(4), 683-709.

Holcombe, R. G. (2002). Political entrepreneurship and the democratic allocation of economic resources. The Review of Austrian Economics, 15(2-3), 143-159.

Holcombe, R. G. (2003). The origins of entrepreneurial opportunities. The Review of Austrian Economics, 16(1), 25-43.

Holcombe, R. G. (2018). Political Capitalism: How Economic and Political Power Is Made and Maintained. Cambridge: Cambridge University Press.

Kamien, M. I., \& Schwartz, N. L. (1982). Market structure and innovation. New York: Cambridge University Press.

Kirzner, Israel M. (2013) Competition and Entrepreneurship. Liberty Fund, (original published in 1973).

Krueger, A. O. (1974). The political economy of the rent-seeking society. American Economic Review, 64, 291-303.

Lee, H., Smith, K. G., Grimm, C. M., \& Schomberg, A. (2000). Timing, order and durability of new product advantages with imitation. Strategic Management Journal, 21(1), 23-30.

MacDonald, James M. and Robert A. Hoppe. (2017) "Large Family Farms Continue to Dominate U.S. Agricultural Production.” United States Department of Agriculture Economic Research Service. 
https:/www.ers.usda.gov/amber-waves/2017/march/large-family-farms-continue-to-dominate-usagricultural-production/, accessed 23 October 2018

MacDonald, James M. and Robert A. Hoppe. (2018) "Examining Consolidation in U.S. Agriculture." United States Department of Agriculture Economic Research Service. https:/www.ers.usda.gov/amberwaves/2018/march/examining-consolidation-in-us-agriculture/, accessed 24 October 2018

Olson, M. (1965). The Logic of Collective Action. Cambridge: Harvard University Press.

Porter, Michael E. (2008) "The Five Competitive Forces That Shape Strategy" Harvard Business Review.

Posner, Richard A. (1974) "Theories of Economic Regulation” NBER Working Paper 41.

Reinganum, J. F. (1985). Innovation and Industry Evolution. Quarterly Journal of Economics, 100(1), 81-99.

Riordan, M. H., \& Williamson, O. E. (December 1985). Asset specificity and economic organization. International Journal of Industrial Organization, 3(4), 365-378.

Schumpeter, J. A. (1943). Capitalism, Socialism, and Democracy. London: George Allen \& Unwin, Ltd..

Sharkey, W.W. (1982). The Theory of Natural Monopoly. Cambridge: Cambridge University Press

Stigler, G. J. (1971). The theory of economic regulation. Bell Journal of Economics and Management Science, 2(1), 3-21.

Stiglitz, J. E. (2012). The Price of Inequality: How Today's Divided Society Endangers the Future. New York: W.W. Norton.

Stockman, D. A. (2013). The Great Deformation: The Corruption of Capitalism in America. New York: Public Affairs Press.

Strandburg, Katherine J. (2014) "Legal but unacceptable: Pallin v. singer and physician patenting norms" in Intellectual Property at the Edge: The Contested Contours of IP, ed. Rochelle C. Dreyfuss and Jane C. Ginsburg. Cambridge: Cambridge University Press.

Tran, J. (2016). Two years after Alice v. CLS Bank. Journal of the Patent and Trademark Office Society, 98, $354-373$.

Tullock, G. (June 1967). The welfare cost of tariffs, monopolies, and theft. Western Economic Journal, $5,224-232$.

Wu, T. (2010). The Master Switch. New York: Alfred A. Knopf, a division of Random House, Inc..

Publisher's note Springer Nature remains neutral with regard to jurisdictional claims in published maps and institutional affiliations. 